\title{
肺癌の非観血的治療
}

\section{II. 非小細胞癌}

\section{Non-Surgical Treatment of Non-Small Cell Carcinoma of the Lung}

宮田佐門

要旨：手術不能な非小細胞癌256例を対象として, 放射線治療効果につき検討した. 結果および 結論として，1)全例の生存率は 1 年 $28.9 \%, 2$ 年 $6.6 \%, 3$ 年 $2.5 \%$, 中間生存期間は 5.9 ヶ月であった。2)病期の進行とともに生存率は低下し, 組織型別成績では, 扁平上皮癌 と腺癌にはほとんど差がなく，大細胞癌は前 2 者より悪い傾向にあった．照射線量別で は, 5000rad以上照射例はそれ以下の例より成績が良く, 線量の増加による腫瘍効果の増 大が成績向上の一因と考えられた．3）I 期では6000rad以上照射することにより根治の可 能性がある。しかし，II期になると，その可能性は極めて低くなる．また，扁平上皮癌 では局所進行例であっても，積極的な治療が延命効果につながると考えられた。

〔肺癌 24( 1 ) : 11 21, 1984]

Key words : Non-small cell carcinoma, Radiotherapy.

\section{はじめに}

肺癌は近年, 他の悪性腫瘍に比較し, 特に発 症率, 死亡数とも増加傾向にある. 集団検診な どによる早期発見の努力および診断, 治療技術 の進歩にもかかわらず, 現実には依然として進 行例が多く, 治療成績も期待された程の向上は みられないものの, しかし, 根治手術可能な早 期例は確実に増え，また進行例に対しては手術， 放射線, 化学, 免疫療法の合併治療の進歩によ ク，徐々に成績は向上している。

放射線治療を主体とした肺癌の成績が悪く, かつわずかの向上しか認められない, その主な 理由として, 非小細胞癌では, 腫瘍自体の放射 線感受性が低いこともあるが, 主に手術適応と ならない進行した症例を対象としていること, さらに最近の外科治療の進歩により手術適応範 囲の拡大があり ’’より一層進行した, 高令化し た症例を対象としていることが言える。

金沢大学放射線科
外科治療の報告では，切除率は $40 \%$ 弱，根治 手術率は $14 \%, 16 \%{ }^{2), 3)}$ と極めて低い結果であ $\eta$, 約 $60 \%$ の切除不能例は, まず放射線治療の 適応が検討されることとなり，放射線治療は手 術との併用として，また切除不能例に対する根 治あるいは対症的治療手段として扱う症例も多 く，役割は重要である。

非小細胞癌の放射線治療では, 腫瘍の放射線 感受性が高くないこと，また腫痬床の耐容線量 も決して多くないことより障害がでやすく，そ のため根治を目的とした場合は肺の放射線耐容 線量いっぱいにまで照射することとなる。しか し, それでも局所治癒, コントロールを得るこ とは，一般に困難であり，また遠隔転移の頻度 も高いことより，放射線治療を実施するにあた っては, 癌の進展範囲および患者の局所, 全身 状態を充分把握した上で注意深く行なわれる必 要がある。

本稿では，手術不能な非小細胞癌に対する放 
Table 1. Age distribution

\begin{tabular}{cc}
\hline Age & Cases \\
\hline $30-39$ & 5 \\
$40-49$ & 18 \\
$50-59$ & 50 \\
$60-69$ & 114 \\
$70-79$ & 64 \\
$80-89$ & 5 \\
\hline Total & 256
\end{tabular}

Table 2. Stage and histological classification

\begin{tabular}{c|ccc|c}
\hline \multirow{2}{*}{ Stage } & \multicolumn{3}{|c|}{ Histology } & \multirow{2}{*}{ Total } \\
\cline { 2 - 4 } & Squamous cell ca. & Adenoca. & Large cell ca. & \\
\hline I & 10 & 9 & 3 & $22(8.6 \%)$ \\
II & 11 & 9 & 4 & $24(9.4 \%)$ \\
III & 85 & 27 & 5 & $117(45.7 \%)$ \\
IV & 53 & 32 & 8 & $93(36.3 \%)$ \\
\hline Total & $159(62.1 \%)$ & $77(30.1 \%)$ & $20(7.8 \%)$ &
\end{tabular}

Table 3. Site of distant metastasis

\begin{tabular}{lc}
\hline Site & Cases \\
\hline Supraclavicular node & 59 \\
Axillary node & 5 \\
Bone & 17 \\
Brain & 12 \\
Liver & 2 \\
Contralateral lung & 10 \\
Spinal cord & 1 \\
Skin & 1
\end{tabular}

Table 4. Radiation dose and stage

$\begin{array}{c|rrrr|c}\hline \multirow{2}{*}{\begin{array}{c}\text { Radiation dose } \\ \text { (rad) }\end{array}} & \multicolumn{4}{|c|}{\text { Stage }} & \multirow{2}{*}{\text { Total }} \\$\cline { 2 - 5 } & \text {$\left.I } & \text { II } & \text { III } & \text { IV } & \\ \hline 0-2900 & 2 & 2 & 21 & 34 & 59 \\ 3000-3900 & & & 7 & 8 & 15 \\ 4000-4900 & 1 & 4 & 17 & 17 & 39\end{array}\right\} 113$

Table 5.

Drugs for chemotherapy and BAI

\begin{tabular}{cc}
\hline Durgs administered intravenously & Cases \\
\hline METT $^{* 1}$ & 22 \\
MFC $^{* 2}$ & 12 \\
Bleomycin & 14 \\
Endoxan & 5 \\
5FU, FT-207 & 20 \\
Others & 16 \\
\hline Total & 89
\end{tabular}

\begin{tabular}{lc}
\hline $\begin{array}{l}\text { Drugs administered through the } \\
\text { bronchial artery }\end{array}$ & Cases \\
\hline $\mathrm{CQ}^{* 3}(6-8 \mathrm{mg})$ & 18 \\
$\mathrm{CQ}(6 \mathrm{mg})+\mathrm{MMC}^{* 4}(4-8 \mathrm{mg})$ & 4 \\
$\mathrm{MMC}(8-20 \mathrm{mg})$ & 11 \\
$\mathrm{MMC}(6-8 \mathrm{mg})+\mathrm{ADM}^{* 5}(20-40 \mathrm{mg})$ & 2 \\
$\mathrm{MMC}(10 \mathrm{mg})+5 \mathrm{FU}(500 \mathrm{mg})$ & 1 \\
\hline \multicolumn{2}{c}{ Total }
\end{tabular}

※1: Mitomycin C, Endoxan, Thio-TEPA, Toyomycin ※2: Mitomycin C, 5FU, Cytosine arabinoside

※3: Carbazilquinon $\quad * 4:$ Mitomycin C $※ 5:$ Adriamycin

射線治療の有効性を腫瘍効果, 生存率, 死因の 面より，また根治，長期生存の可能性について， さらにBAI(bronchial arterial infusion)併用効果 の面より検討した。

\section{対}

昭和43年 1 月より56年 1 月まで, 金沢大学放 射線科で治療し，かつ組織型の確定した非小細 胞癌256例（切除, 既治療例は除く）を対象とし
た。男222例, 女34例, 年令分布では60才代に最 も多く, 平均年令は63.9才であった (Table1.). 病理診断は組織診による161例, 細胞診による 95 例であった。組織型では扁平上皮癌159例, 腺癌 77例，大細胞癌20例であったＵICCのTNM分 類(1978年)を加味した日本肺癌学会臨床病期分 類によると I 期 22例，II 期 24例，III期117例，IV 期93例であった(Table2.). 主な遠隔転移の部位 では鎖骨上窩リンパ節，骨，脳，対側肺，肺門 
Table 6. Effect of radiation therapy evaluated by chest X-ray film findings

\begin{tabular}{|c|c|c|c|c|c|c|c|c|c|}
\hline \multirow[t]{2}{*}{$\begin{array}{l}\text { Radiation dose } \\
\quad \text { (rad) }\end{array}$} & \multicolumn{3}{|c|}{$\begin{array}{l}\text { Squamous cell ca. } \\
\text { (79 cases) }\end{array}$} & \multicolumn{3}{|c|}{$\begin{array}{l}\text { Adenoca. } \\
\text { (39 cases) }\end{array}$} & \multicolumn{3}{|c|}{$\begin{array}{l}\text { Large cell ca. } \\
\text { (12 cases })\end{array}$} \\
\hline & \# & + & - & $H$ & + & - & H & + & - \\
\hline $\begin{array}{c}0-2900 \\
(15 \text { cases })\end{array}$ & 0 & 0 & 8 & 0 & 0 & 15 & 0 & 0 & 2 \\
\hline $\begin{array}{c}3000-4900 \\
(29 \text { cases })\end{array}$ & 4 & 4 & 13 & 0 & 1 & 5 & 0 & 2 & 0 \\
\hline $\begin{array}{c}5000-8000 \\
(86 \text { cases })\end{array}$ & 12 & 16 & 22 & 6 & 13 & 9 & 3 & 4 & 1 \\
\hline
\end{tabular}

\# : Marked effect + : Moderate effect $\quad-$ : No effect

が多かった(Table3.). 局所(原発巣または肺門， 縦隔リンパ節転移) の照射量では, 6000-6900 $\operatorname{rad}$ が最も多く, 以下Table4.の如くであった。 尚, 5000rad以上照射例の遠隔転移の部位では, 85\%の例が鎖骨上窩リンパ節であった。

\section{治療方法}

放射線治療では，大部分の例で ${ }^{60} \mathrm{Co}$ またはリ ニアック10MVX線を使用し, 150-200 rad/回, 週 5 回照射で, 根治を目的とした場合は総線量 で 5000-7000rad，対症的な場合は 3000-4000 $\operatorname{rad}$ を投与された。照射範囲は原発巣, 肺門, 縦 隔を含めてとし，3000-5000radで残存病巣に縮 小した。

全身化学療法は89例に施行し, その内訳は METT, MFC, Bleomycin, 5FU, FT-207が多 かった(Table5.)。また, 36例でCQ，MMCを主 体としたBAIを施行した(Table5.).

生存期間の集計は 57 年 2 月の時点で行った。

\section{結 果}

1）胸部X-P上の放射線治療効果( Table6.). 効果判定可能な腫瘤で, BAI併用例を除いた扁 平上皮癌79例, 腺癌39例, 大細胞癌 12 例の計130例 を対象とした。平均腫瘤直径比で75\%以上縮小 した例を著効，75-25\%縮小した例を有効，そ れ以下の縮小例を無効とした。著効，有効例は 3000rad以下で0/15, 0/15, 3000-4900radで4/29 (13.8\%), 7/29(24.1\%), 5000rad以上で21/86 (24.4\%),33/86(38.4\%)であった。線量の増加
とともに腫瘍縮小例も増加した。腫瘤の大きさ については，5 cm以下と以上に分けて評価した が，線量と縮小率に差がみられなかった。組織 型別には大細胞癌, 扁平上皮癌, 腺癌の順で縮 小率が良い傾向にあった。

2) 生存率(Table7.)

(1) 全例の生存率は 1 年 $74 / 256(28.9 \%), 2$ 年 $15 / 229(6.6 \%), 3$ 年 $5 / 202(2.5 \%)$, 中間生存期 間は 5.9 ケ月であった。 1 年, 2 年で急激な生存 率の低下がみられ， 3 年以後は， 3 年 3 ヶ月で 腫瘍死した 1 例を除いた 4 例で 5 年以上再発な く生存している。

(2) 全身化学療法併用の効果では, 1 年生存率, 中間生存期間は併用例で $26 / 89(29.2 \%), 5.9$ ヶ 月, 非併用例で $48 / 167(28.7 \%), 5.8$ 个月と両群 に差がなく，組織型別にみても， \pm 1.5 ケ月以内 であった．全身化学療法併用による延命効果は 認め難い結果であった。

(3) 病期別では 1 年生存率, 中間生存期間は I 期 $13 / 22(59.1 \%) ， 16.1$ ヶ月， II 期 $14 / 24(58.3$ $\%), 11.1$ ヶ月, III期 $30 / 117(25.6 \%), 6.1$ ヶ月, IV 期17/93(18.3\%)，4.0ヶ月であった。病期の 進行とともに生存率の低下がみられた。

(4) 組織型別では 1 年生存率, 中間生存期間は 扁平上皮癌 $48 / 159(30.2 \%), 5.7$ ヶ月, 腺癌 $23 / 76$ $(30.3 \%), 6.3$ ヶ, 大細胞癌 $3 / 21(14.3 \%)$, 4.8ヶ月であった。扁平上皮癌と腺癌では成績に ほとんど差がなく, 大細胞癌は症例が少ないが, 前 2 者より悪い傾向にあった。尚， 3 年以上生 存例では扁平上皮癌が 5 例中 4 例と多かった。 
Table 7. Relation between survival rate and stage, histology, radiation dose

\begin{tabular}{|c|c|c|c|c|}
\hline \multirow{2}{*}{ Stage } & \multicolumn{3}{|c|}{ Survival rate } & \multirow{2}{*}{$\begin{array}{l}\text { Median } \\
\text { survival } \\
\text { months }\end{array}$} \\
\hline & 1-year & 2-year & 3-year & \\
\hline $\mathrm{I}$ & $13 / 22(59.1 \%)$ & $5 / 18(27.8 \%)$ & $2 / 15(13.3 \%)$ & 16.1 \\
\hline II & $14 / 24(58.3 \%)$ & $2 / 24(8.3 \%)$ & $1 / 22(4.5 \%)$ & 11.1 \\
\hline III & $30 / 117(25.6 \%)$ & $6 / 101(5.9 \%)$ & $1 / 88(1.1 \%)$ & 6.1 \\
\hline IV & $17 / 93(18.3 \%)$ & $2 / 86(2.3 \%)$ & $1 / 77(1.3 \%)$ & 4.0 \\
\hline $\begin{array}{l}\text { Total } \\
\text { Histology }\end{array}$ & $74 / 256(28.9 \%)$ & $15 / 229(6.6 \%)$ & $5 / 202(2.5 \%)$ & 5.9 \\
\hline Squamous cell ca. & $48 / 159(30.2 \%)$ & $10 / 141(7.1 \%)$ & $4 / 119(3.4 \%)$ & 5.7 \\
\hline Adenoca. & $23 / 76(30.3 \%)$ & $5 / 69(7.2 \%)$ & $1 / 67(1.5 \%)$ & 6.3 \\
\hline $\begin{array}{l}\text { Large cell ca. } \\
\text { Radiation dose (rad) }\end{array}$ & $3 / 21(14.3 \%)$ & $0 / 19(0 \%)$ & $0 / 16(0 \%)$ & 4.8 \\
\hline $0-2900$ & $10 / 59(16.9 \%)$ & $0 / 54(0 \%)$ & $0 / 51(0 \%)$ & 2.7 \\
\hline $3000-3900$ & $0 / 15(0 \%)$ & $0 / 14(0 \%)$ & $0 / 13(0 \%)$ & 4.5 \\
\hline $4000-4900$ & $11 / 39(28.2 \%)$ & $2 / 33(6.1 \%)$ & $0 / 27(0 \%)$ & 4.3 \\
\hline $5000-5900$ & $10 / 28(35.7 \%)$ & $2 / 23(8.7 \%)$ & $0 / 20(0 \%)$ & 5.8 \\
\hline $6000-6900$ & $29 / 91 \quad(31.9 \%)$ & $6 / 81(7.4 \%)$ & $2 / 67(3.0 \%)$ & 9.3 \\
\hline $7000-8000$ & $14 / 24(58.3 \%)$ & $5 / 24(20.8 \%)$ & $3 / 24(12.5 \%)$ & 14.5 \\
\hline
\end{tabular}

Table 8. Causes of death

\begin{tabular}{lc}
\hline Cause of death & Cases \\
\hline Progression of chest tumor & 144 \\
Lymphangitis & 3 \\
Pneumonia & 4 \\
Distant metastasis & \\
Bone & 22 \\
Brain & 19 \\
Lung (multiple) & 6 \\
Generalized & 12 \\
Liver & 3 \\
Spinal cord & 2 \\
Others (Cardiac failure, Tongue ca, etc) & 5 \\
\hline
\end{tabular}

(5)照射線量別では線量の増加とともに生存率 の向上と中間生存期間の延長が認められた. 5000 $\mathrm{rad}$ で分けて評価すると, 1 年生存率, 中間生存 期間は5000rad以上で53/143(37.1\%)，9.2ヶ月， $5000 \mathrm{rad}$ 以下で21/113(18.6\%)，3.4ヶ月と5000 $\operatorname{rad}$ 以上の成績が良く $(p<0.005)$, さらに, 2 年 以上生存例の $13 / 15(86.7 \%)$ を占め, 3 年以上生 存例は6000rad以上でのみみられることより, 線 量の増加による腫瘍効果の増大が成績向上の一
Table 9. Summary of stage I and II cases

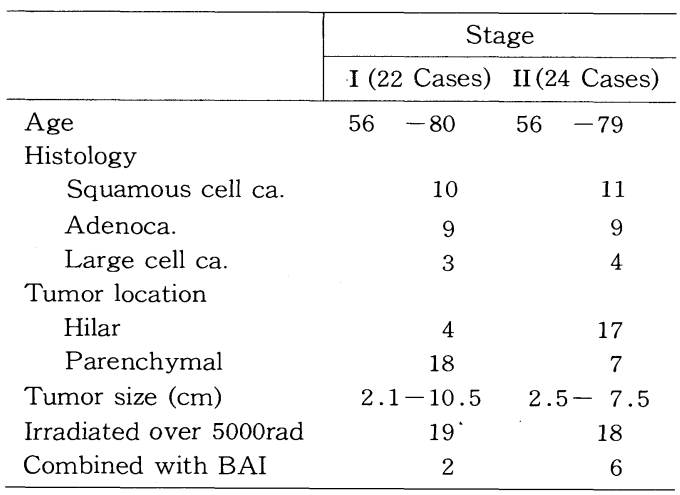

因となっていると考えられる。

3) 死因 (Table8.)

昭和 46年以後の症例で死因の判断が臨床的に 可能であった187例では, 胸部病変の進行が関係 する144例 (77.0\%), Lymphangitis 3 例 (1.6\%), 肺炎 4 例 $(2.1 \%)$, 遠隔転移が関係する, 骨 22 例 $(11.8 \%)$, 脳 19 例 $(10.2 \%)$, 多発性肺転移 6 例 $(3.2 \%)$, 肝 3 例 $(1.6 \%)$, 脊髄 2 例 $(1.1 \%)$, 全 身転移12例 $(6.4 \%)$ であった。結局, 胸水, 心の 
Table 10. Cases surviving more than two years

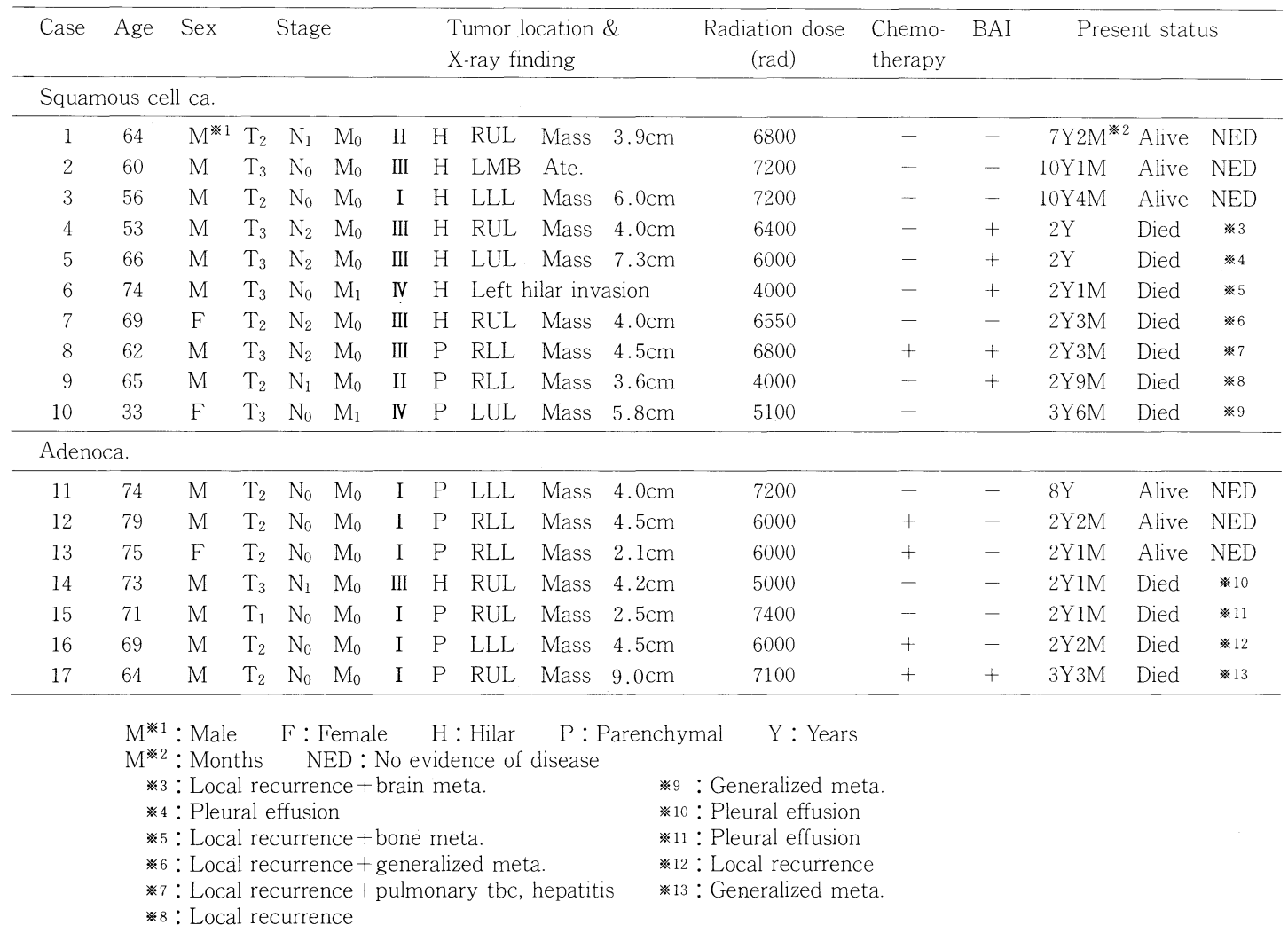

お液貯留および胸壁，椎体，縦隔などへの腫瘍 進展を含めた胸部病変の進行が関係する割合が $80.7 \%$ と多かった。また，遠隔転移が関係する 割合も $34.2 \%$ はられた。

4）非小細胞癌の放射線治療による根治および 長期生存の可能性を検討する目的で，I， II 期 例および 2 年以上生存例を取り上げ分析した。 症例の内訳はTable9,10に示めした。

(1) I 期22例では， 1 年 3 例（内 2 例は集計時 点以後も再発なく生存中であり，2 年以上とな る), 8 年 1 例, 10 年 1 例の計 5 例で再発なく生 存中である。この内訳は扁平上皮癌 2 例, 腺癌 3 例であり, 胸部 X 線像では肺門型 1 例, 肺野 型 4 例，腫瘍の大きさ（長径）では2.1-6.0cm ( 4 例は $5 \mathrm{~cm}$ 以下) であり，照射量は6000rad 3 例，7200rad 2 例であった。他は，5000rad以下 に終った 3 例は 5 ヶ月ー 1 年 8 ヶ月で喀血およ び局所腫瘍進行により死亡した５000rad以上の 14 例では， 7 ケ月ー 2 年 3 ケ月で死亡しており， 経過の明らかな 9 例で, 1 例は 1 年 8 ケ月後再 発はなかったが，心不全で死亡，5例で喀血， 胸水貯留, 肺炎併発を含む局所腫陽進行が関係 し， 3 例で骨，脳，全身転移が関係していた。 結局，5000rad以上照射できた例でみると6/19 $(31.6 \%)$ に最低 1 年 8 ケ月以上再発がなかった こととなる。一方，死因では局所腫瘍進行が関 係する場合が多く，局所コントロールを得るこ とが困難であることが言える。

(2) II 期 24 例では, 扁平上皮癌の 1 例で6800rad 照射により 7 年再発なく生存中である。他は, $5000 \mathrm{rad}$ 以下に終った 6 例では，1例は4000rad 照射とBAI 2 回施行により比較的経過は良かっ たが, 2 年 9 ケ月後原発巣の悪化により死亡し, 他の 5 例は 5 ヶ月 -1 年 1 ケ月で死亡しており, 
経過の明らかな 4 例全例で局所腫瘍進行が， 2 例で遠隔転移が関係していた。 $5000 \mathrm{rad}$ 以上 17 例では 3 ヶ月 -1 年 7 ヶ月で死亡しており, 経 過の明らかな10例中 9 例で局所腫瘍進行が, 3 例で遠隔転移が関係していた。結局, II 期で は, 再発なく生存は 1 例のみであって，I 期に 比較し成績は劣り, 局所コントロールを得るこ とが，さらに困難であると言える。

(3) 2 年以上生存例は $15 / 229(6.6 \%)$ と極く少 数であり，長期生存例として取り上げた。また 集計時点以後も生存し， 2 年に達した 2 例を加 之, 計17例を検討した(Table10。). 扁平上皮癌 10 例, 腺癌 7 例, 大細胞癌なL, I 期 7 例, II 期 1 例, III 期 6 例, IV 期 2 例（鎖骨上窩りンパ 節転移)であった。照射量では4000rad 2 例, 5000 $\operatorname{rad} 2$ 例, 6000rad以上13例であった。組織型と 病期の関係では, 扁平上皮癌で III， IV 期が10例 中 7 例と意外に多く, 腺癌で I 期が 7 例中 6 例 と多かった，死因では局所腫瘍進行が関係する 例が11例中 9 例と多く, 遠隔転移が関係する 11 例中 5 例であった。

I , II 期おょび 2 年以上生存例の分析からは, I 期は6000-7000rad照射することにより根治を 得ることも可能である。しかし，I期であって も局所腫瘍進行により死亡する場合が多いこと より，局所コントロールを得ることは非常に困 難であると言える。また，II期になると根治の 可能性は極めて低くなる。一方，扁平上皮癌で は局所進行例であっても，4000-7000radの照射 と BAI併用により，少数例ではあるが長期生存 が得られることょり, 積極的治療が生存率向上 の面より重要であると考えられる。

5） BAI併用効果

対象は扁平上皮癌 24 例, 腺癌 10 例, 大細胞癌 2 例の計 36 例である. I 期 3 例, II 期 7 例, III 期18例, IV 期 8 例であり, BAI 1 回施行 28 例, 2 回施行 8 例であり, 照射量では5000rad以上 20 例である。BAI併用 36 例の生存率は 1 年 $12 / 36$ $(33.3 \%), 2$ 年6/34 $(17.6 \%), 3$ 年以後の生存 はなく, 中間生存期間は 7.8 个五でた。特に 2 年生存率が比較的良い傾向にあり，2 年生存 6 例中 1 例は腺癌であるが, 5 例は扁平上皮癌
であり，全例における 2 年生存例の6/15(40\%) を占めており，また $4000 \mathrm{rad}$ 照射例の内で 2 年以 上生存した2例をも占めていることより, BAI併 用は確実に延命効果を有すると考えられる。胸部 $\mathrm{X}-\mathrm{P}$ 上の腫瘤縮小効果でも, 3000 rad 以上で著 効, 有効率は $6 / 12,4 / 12$ と放射線単独治療上り良 い傾向にあった。結局, BAI併用により局所腫瘍 効果の増強を得ることが可能であり，しいては 生存率の向上につながると言える。しかし， 3 年以後の生存はないことより, BAI を併用して も完全な局所コントロールを得るには困難があ ると考えられる。

\section{考案}

現在, 肺癌治療上の主な問題点として，いく つかの事実が上げられる。発症率が高い. high risk群のスクリーニング法の成果が充分あがって ない．大部分の症例が初診時, すでに進行して おり外科治療の適応とならない2.3) 血行性転移 の頻度が高い. 部位的に大線量を投与できない4. 非小細胞癌では化学療法の効果が小さい5) この 様な解決困難な問題はあるにせよ，近年，肺癌 に関する生物学, 病理学上の基礎知識の向上と 診断，治療技術の進歩が相俟って，短期的には 治療成績の著明な向上は期待できないものの， 症例個々の組織型，進行度および全身状態に応 じた適切な治療方針が確立されつつある。

非小細胞癌の治療法として, 最も確実な方法 は外科治療である。しかし，はじめに述べた如 く，根治手術率は極めて低く，かつ根治手術が 可能であった症例でも 5 年生存率は $57.5 \%$ と 決して良い成績とは言之ない。さらに，III期例 では切除例は低く, 切除可能であっても5 年生 存率は $5.6 \%, 13.6 \%$ と著しく悪い.

一方，放射線治療はもう一つの根治的治療手 段であるが, 症例の選択にもよるが, 2.9-10 $\%(6) \sim 10) の 5$ 年生存率は得られるものの, 大多数 の症例は局所腫煬進行あるいは遠隔転移により 2 年以内に死亡する。当科の症例でも III， IV 期 の占める割合が $82 \%$ と高率であり，また年令を みると, 70 才以上の占める割合は 50 年以前で $16.2 \%$ ，それ以後は $35.2 \%$ と最近はより高令化 
している.この様に進行例, 高令者が多く， 2 年以上生存例が多く得られている5000rad以上照 射できた例をみても，全体の $55.9 \%$ に過ぎ なかった。

しかし, 放射線治療の役割は症状緩解ととも に, 全身状態が良く, 腫瘍が限局している場合 には治瘾が得られる例も少数ながら存在するこ とより確かに根治治療手段でもあるが, どの様な 症例にどの様な内容の放射線治療が施行された場 合, 根治あるいは長期生存が得られるかに関し ては, 明確な事実はなく，この点充分研究がな されるべきである。

非小細胞癌の放射線治療による生存率からみ た有効性に関しては, Slawsonら ${ }^{11)}$ は, , 進行肺 癌は放射線治療が施行されても治癒例は極く一 部であり, 大部分の症例は生存期間が短かく, 放射線治療は対症的な意味しかなく, 症状緩解 と生存の質的向上に目的があるとした。 Roswit $ら^{12)}$ は, 局所進行手術不能肺癌554例で, 4000$5000 \mathrm{rad} / 4-5$ 週照射群と placebo群で比較し,

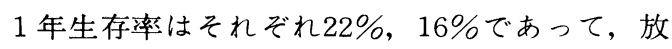
射線治療による延命効果は小さいとし，また， Berry ${ }^{13)}$ は, 3500-4000rad/25日照射例と化学 療法例, 非治療例を比較し, 放射治療例に生存 率の向上は認められないと報告した。この様な 放射線治療の有効性に関して悲観的な報告もあ るが, しかし, 以上の報告は照射量が3500-5000 $\mathrm{rad}$ と比較的少ないことが, 腫瘍効果を充分得る ことができず，延命効果につながらなかったこ との原因の一つと考えられる。

他方, Berkley ${ }^{14)}$ は, パンコース型を除く585 例で中間に 1 ヶ月の休止期間を置く, 3000 rad $/ 10$ 回を 2 回照射のsplit course治療を計画した所, 約 $50 \%$ 症例が局所腫瘍進行, 遠隔転移の出現, 全身状態の悪化, 死亡などの理由で後半の治療 ができなかったが, しかし, 後半の治療が可能 であった例では, 前半の治療のみに終った例に 比較し, 平均生存月数で2倍以上に延長していた と述べた.Petrovichら ${ }^{15)}$ は, 局所腫瘍進行および 内科的合併症のため切除不能な肺癌345例の分析 より, 線量が中間生存期間に最も関係し, 1500 ret 以下で6.8ヶ月，1501-1600ret で8.1ヶ月, 1600ret以上で10.2ヶ月,さらに1700ret以上では 18.3 个月と, 線量の増加とともに中間生存期間 の延長が認められ, 1600-1700ret で最も良い放 射線治療効果が得られると述べた. Salazarら ${ }^{16)}$ は，200例の検討より1469ret以上照射例では有 意の差はないが, それ以下の照射例より明らか に生存率が高かったとし, 総量で6000 radの照 射を勧めている。また, Coyら ${ }^{10)}$ は, Karnofsky scaleで70\%以上の141例に5000-5750radの根治 的放射線治療を施行し，1年生存率57\%， 5 年 生存率10\%を, Slawson ら ${ }^{17)}$ は, 無症状の III 期 48例に5500-6000rad照射し, 3 年生存率10\%の 成績をそれぞれ得ており，Guttman ${ }^{18)}$ は，切除 可能と考えられたが試験開胸に終った95例に $5000 \mathrm{rad}$ 照射し，1 年生存率 $57 \%, 5$ 年生存率 7.4 \%と臨床的に手術不能で照射した例より成績が 良かったと報告した。この様に進行度, 全身状 態, 線量と予後に密接な関係があり, 根治的照 射の適応となる症例を選択し, 5000-6000rad照 射することにより比較的良い成績が得られ, 根 治的放射線治療の価值が見い出せる. 当科の結 果でも5000rad以上の照射で1年生存率 $36.4 \%$ と 成績は良いとは言之ないが, 2 年生存例の $13 / 15$ (86.7\%)を占めており,さらに6000-8000rad照 射で 3 年以上生存 5 例をも得られた。また, 5000 $\operatorname{rad}$ 以上照射例の中で, 予後を悪くする因子とし て上大静脈症候群, パンコース卜型, 骨浸潤, 鎖 骨上窝りンパ節, 遠隔転移を有する例を除くと 1 年生存率は $41 / 85(48.2 \%)$, 中間生存期間は 12.9 ケ月とさらに良くなる。根治を目的とした放射線 治療が可能な例で, 長期生存を得ようとした場 合には5000radは最低必要な線量と考えられる.

非小細胞癌の放射線治療に上る局所腫瘍効果 に関しては, 局所腫瘍進行による死亡が最も多 く, そのため, 放射線治療による腫瘍縮小の程 度, 局所コントロールの有無が予後に最も関係 する. 下里ら ${ }^{19)}$ は, 照射後切除例の病理組織学 的検討より, 組織学的に著明な効果 $\left(\mathrm{II} b-\mathrm{IV}^{19)}\right)$

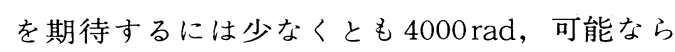
5000rad以上必要であるとし, Rissanen ら ${ }^{20)}$ は, 4000-7000rad照射した剖検例より, 扁平上皮癌 で7/26(26.9\%)に腫瘍細胞がなかったと報告し 
た。また，線量と腫瘍縮小率，局所コントロー ルについては, Perezら ${ }^{21)}$ は, 4000-6000radを splitまたはcontinuous courseで照射し，腫瘍が $\mathrm{X}-\mathrm{P}$ 上消失した例は大細胞癌で $32 \%$, 腺癌で 25 胸部 X-P上消失した例は大細胞癌で $32 \%$, 腺癌で $25 \%$, 扁平上皮癌で $13 \%$, 線量との関係では5000 って, 5000-6000radで最も局所腫瘍効果が高く, 局所再発率が低いと報告した。 Emamiら ${ }^{22)}$ は, 局所コントロール(経過中での)照射野内の病巣の 増大, 悪化がない)率はsplit courseの6000rad で 41/70(58.5\%), continuous course の5000rad で 10/22(45.5\%)であったとし, Shermanら ${ }^{8)}$ は, 4000－5000radでは局所再発率は50\%であるが, 線量の増加とともに再発率は低下し, 6000rad以 上では $5 \%$ であると報告した。この様に4000$6000 \mathrm{rad}$, 特に5000rad以上で良い局所腫瘍効果 が得られ，さらに線量を多くしても，それに比

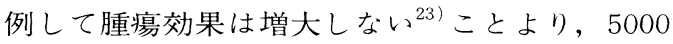
-6000radが最適当な線量と考えられる。しか し, 最大の局所腫痬効果が得られ, なおかつ最 小の障害で抑えることのできる，最適な放射線 治療内容が種々検討されているものの, まだ確 立されておらず，今後さらに研究が必要である と考える.

非小細胞癌の放射線治療による根治および長 期生存の可能性に関しては, Sherman ら ${ }^{8)}$ は,

I , II 期 14 例中 11 例で18ヶ月以上再発なく生存 していると報告した。 Smart ${ }^{24)}$ は，全身状態が良 く, 腫瘍が限局しており, リンパ節転移なく, 手術可能な40例で放射線治療を施行し, 5 年生存 率22.5\%を得ている。野ら ${ }^{6)}$ は, I 期6/27(22.2 $\%)$, II 期 $3 / 18(16.7 \%)$ の 5 年生存率であったこ とより, 全身状態が悪いために手術ができなか ったことを考慮に入れると，I，II期例では放 射線治療のみでも手術に匹敵する成績が得られ ると考察した。当科の結果でも5000 rad以上照射 例の 5 年生存率は I 期で $2 / 11(18.2 \%)$, II 期で $1 / 12(8.3 \%)$ であるが，I 期 19 例中 6 例で最低 1 年 8 ケ月再発なく，4例で 2 年以上生存中であ ることより, 少数例ではあるが根治を得ること は可能であると言える。また, 組織型別に分析 すると, 扁平上皮癌 I 期の 5 年生存率は $1 / 7^{25)}$
$1 / 5^{6}$, 当科の結果でも $1 / 4$ と同様な結果であり， 肺門部扁平上皮癌は肺障害の面より大線量を投 与できず，根治を得るのは困難があることは事 実だが，少数例ではあるが可能と思われる。ま た，腺癌のI 期では，小野ら ${ }^{6)}$ は， 5/15の 5 年 生存率であって, 扁平上皮癌より腺癌に良い傾 向があり，5年生存例はすべて末梢型で, 内 4 例は上肺野に腫瘍があり大線量を投与しても障 害の程度は少ないだろうと判断され，小照射野 にて10000-13000radの大線量の照射ができた例 であったと述べた。当科の結果でも， 5 年生存 率は $1 / 5$ であったものの, 9 例中 3 例で 2 年 1 ケ 月以上再発なく生存していることより, 6000rad 以上照射することにより扁平上皮癌よりも根治 を得られる可能性が大きいと考えられる。II期 では, 金田ら ${ }^{25)}$ の 5 年生存率は $1 / 19$ であり, 当

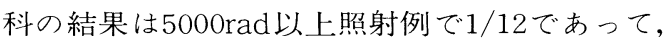
再発なく生存は 1 例のみであることより，まず 根治を得ることは無理と考えられる。現実には， I 期であっても根治を得ることは非常に困難で あるが, 高令あるいは内科的合併症のため手術 不能の例では, 放射線治療により少数例ではあ るが根治を得られることは事実である。一方, 扁平上皮癌は局所進行例であっても, 4000-7000 $\operatorname{rad}$ 照射と症例によってはBAIを併用すること により，かなりの腫瘍効果を得られることより 積極的な治療が延命につながると考えられる。 また，腺癌のII 期以上では， 2 年生存は 1 例の みであることより扁平上皮癌程には長期生存を 得がたいと考えられる。

肺癌の放射線治療にともなう障害に関しては, 放射線肺炎, 線維症, 食道炎, 心臓炎, 脊髄炎 が重要である。その中でも肺障害が治療上の最 大制限因子であり，照射範囲，線量，分割回数， 症例個々の反応性が障害の程度を左右する。 Deely ${ }^{26)}$ は, 切除不能な未分化癌102例で3000 $\mathrm{rad} / 20$ 回/ 4 週照射群と4000rad/20回/4 週照射 を比較し， 2 年生存率, 中間生存期間は, それ ぞれ $6 \% ， 9.3$ ケ，0\%，6.0ケ月であり，両 群の残存病巣, 転移の頻度は変わらないが, 4000 $\operatorname{rad}$ 照射群では肺線維症の頻度が高く, そのため 予後は悪いと結論し, Rubin ら ${ }^{27)}$ は, 一葉の照射 
では 5 年で $1-5 \% ， 25-50 \% に$ 重篤な障害を きたす線量は4000rad, 6000radと述べた如く, 線量の増加とともに肺障害も増加する。 $5000 \mathrm{rad}$ 以上照射の場合には放射線肺炎, 線維症は程度 の差はあれ必発であるが，注意樑く行なわれた 治療においては，それが直接死因となることは 少ないが，感染を併発した場合は難治性となり やすく，それが死因となることは充分起こり得 る. 従って, 5000rad以上照射する場合は30005000radで照射範囲の縮小, 休止期間を置くなど の綿密な配慮が必要である。

放射線治療とBAI併用に関しては, 非小細胞 癌の放射線治療では, 前述した如く, 正常組織 障害なしに病巣に充分な線量を投与することが 困難なため, 正常組織障害が少なくして局所腫 瘍効果を有するBAI併用は合理的な治療法であ り, 放射線治療との併用により局所腫瘍効果の 増強が期待される。下里ら ${ }^{28)}$ は, BAI 施行後切 除29例の病理組織学的検討より, MMC 10-20 $m g$ 注入は, 下里らの組織学的効果判定基準 ${ }^{19)}$ で grade I - IVの効果を示めし, 術前照射の効果と 比較した場合に腫癔全体でみると分割照射の 2000 $\mathrm{rad}$, 部分的には3000-4000 radに相当する部位 もあり, 扁平上皮癌, 未分化癌に有効例が多い と報告した。 小野ら ${ }^{6)}$ は, 放射線治療と MMC10 $\mathrm{mg}$ の BAI併用 111 例の 1 年, 3 年生存率は $56.3 \%$, $14.9 \%$ ，それに対して放射線治療単独では33.3 $\% ， 6.5 \%$ あっあて, BAI併用により生存期間の 延長, 生存状況の質的向上が期待できると報告 した。当科の結果でも, BAI併用例は非併用例 に比較し, 局所腫瘍効果は大きく, 3 年生存例 はなかったが 2 年生存率は良く, 局所腫瘍効果 の増大による延命効果の面ですぐれた手段であ ると考えられる。

\section{結 語}

手術不能な非小細胞癌256例を対象として,放 射線治療の有効性を生存率, 根治および長期生 存の可能性, BAI 併用効果の面より検討した。
結論として，

1 . 全例の生存率は 1 年 $74 / 256(28.9 \%), 2$ 年 $15 / 229(6.6 \%), 3$ 年 $5 / 202(2.5 \%)$, 中間生存 期間は 5.9 个月であった。 1 年, 2 年で急激な 生存率の低下がみられた。

2 . 病期別では 1 年生存率, 中間生存期間は I 期13/22(59.1\%), 16.1ヶ月, II 期14/24(58.3 $\%), 11.1$ ヶ, III 期 $30 / 117(25.6 \%), 6.1$ ヶ 月， IV 期17/93(18.3\%)，4.0ケ月であった。 病期の進行とともに生存率の低下がみられた。 組織型別成績では, 扁平上皮癌と腺癌でほと んど差がなく, 大細胞癌は前 2 者より悪い傾 向にあった。また，照射線量別では，5000 rad 以上照射例で成績が良く，線量の増加による 腫瘍効果の増大が成績向上の一因と考えられ た。

3. 死因では胸部病変の進行が関係する割合が $80.7 \%$ と多く,遠隔転移が関係する割合も 34.2 \%にみられた。

4. I 期例では, 6000rad以上照射することによ り少数例ではあるが, 根治を得ることは可能 である。しかし，一般に原発巣のコントロー ルを得ることは非常に困難である。II期例で は根治の可能性は極めて低い。また, 扁平上 皮癌は局所進行例であっても, 4000-7000 rad の照射, 症例によってはBAIを併用すること により，少数例だが長期生存が得られること より積極的な治療が重要である。

5. 放射線治療と BAIを併用することにより, 局所腫瘍効果の増強が得られ，生存期間の延 長が期待できる。しかし，BAIを併用しても 完全な局所コントロールを得るには困難があ る.

\section{謝 辞}

稿を終るに臨み, 御指導, 御校閲を賜った恩師高島力 教授に心から謝意を表します。また本研究を行うに当た り，御協力を賜った教室の先生方に感謝いたします。 
1）岩喬, 渡辺洋宇：進行肺癌に対する補助療 法併用による拡大手術の成績とその意義 肺癌, 21 : 427-437, 1981.

2）早田義博, 船津秀夫, 会田征彦, 他：進行肺癌 の外科. 胸部外科, $30: 626-633,1977$.

3) Naruke, T., Suemasu, K., Ishikawa, S. : Surgical treatment for lung cancer with metastasis to mediastinal lymphnodes. J. Thorac. Cardiovasc. Surgery, 71 : 279-285, 1976.

4) Phillips, Th. L., Margolis, L. : Radiation pathology and the clinical response of lung and esophagus. Radiation effect and tolerance, normal tissue. Front. Radiation Ther. Onc., 6 : 254-273, 1972.

5）小室康男, 米田修一, 本間 威, 他：肺のNonSmall Cell Carcinoma に対する ACOM おょび COM療法の治療成績. 肺癌, 21 : 543-551, 1981.

6）小野良祐, 砂倉瑞良, 北川俊夫, 他：放射線に よる肺癌治療に関する研究. 肺癌, 16 : 343-355 1976.

7) Caldwell, W.L., Bagshaw, M.A. : Indications for and results of irradiation of carcinoma of the lung. Cancer, 22 : 999-1004, 1968.

8) Sherman, D.M., Weichselbaum, R., Hellman, S. : The characteristics of long-term survivors of lung cancer treated with radiation. Cancer, 47 : 2575-2580, 1981.

9）中川英二：肺癌の放射線治療に関する臨床的研 究. 日医放会誌，35：119-141，1975.

10) Coy, P., Kennelly, G.M. : The role of curative radiotherapy in the treatment of lung cancer, Cancer $45:$ 698-702, 1980.

11) Slawson, R.G., Scott, R.M. : Radiation therapy in bronchogenic carcinoma. Radiology, 132 : 175-176, 1979.

12) Roswit, B., Patno, M.E., Rapp, R., et al. : The survival of patients with inoperable lung cancer : A large-scale randomized study of radiation therapy versus placebo. Radiology, 90 : 688-697, 1968.

13) Berry, R.J., Laing, A.H. : The role of radiotherapy in treatment of inoperable lung cancer. Int. J. Radiation Oncol. Bio. Phys., 2 : 433-439, 1979.

14) Barkley, H.T. : Textbook of radiotherapy, ed by Fletcher, G.H. 3rd Ed., Lea \& Febiger, 664-688, Philadelphia, 1981.

15) Petrovich, Z.P., MietLowski, W., Ohanian, M., et al. : Clinical report on the treatment of locally advanced lung cancer. Cancer, 40 : 7277, 1977.

16) Salazar, O.M., Rubin, P., Brown, J.C., et al. : Predictors of radiation response in lung cancer. A clinico-pathological analysis. Cancer, 37 : 2636-2650, 1976.

17) Slawson, R.G., Scott, R.M. : Radiation therapy for patients with asymptomatic lung cancer. Radiology, 135 : 481-484, 1980.

18) Guttmann, R.J. : Results of radiation therapy in patients with in operable carcinoma of the lung whose status was established at exploratory thoracotomy. Am. J. Roentgenol., 93 : 99103, 1965.

19）下里幸雄, 尾形利郎：病理学的にみた肺癌の術 前照射. 肺と心, $13: 332-338 ， 1966$.

20) Rissanen, P.M., Tikka, U., Holsti, L.R. : Autopsy findings in lung cancer treated with megavoltage radiotherapy. Acta Radiologica Therapy Physics Biology, 17 : 433-442, 1968.

21) Perez, C.A., Stanley, K., Rubin, P., et al. : A prospective randomized study of various irradiation dose and fractionation schedules in the treatment of inoperable non-oat-cell carcinoma of the lung. Cancer, $45: 2744-2753,1980$.

22) Emami, B., Munzenrider, J.E., Lee, D.J., et al. : Radical radiation therapy of advanced lung cancer. Evaluation of prognostic factors and results of continuous and split course treatment. Cancer, 44 : 446-456, 1979.

23) Eisert, D.R., Cox, J.D., Komaki, R. : Irradiation for bronchial carcinoma. Reasons for failure. 1. Analysis of local control as a function of dose, time, and fractionation. Cancer, $37: 2665$ $-2670,1976$.

24) Smart, J. : Can lung cancer be cured by irradiation alone? JAMA, 195 : 1034-1035, 1966.

25）金田浩一, 木下 厳, 中川 健, 他： I , II 期, 肺癌の放射線治療. 肺癌, $17: 289-297,1977$.

26) Deely, T.J. : A clinical trial to compare two different tumor dose levels in the treatment of 
advanced carcinoma of the bronchus. Clin.

Radiol., 17 : 299-301, 1966.

27) Rubin, P., Casarett, G. : A direction for clinical radiation pathology. The tolerance dose. Radiation effect and tolerance, normal tissue.
Front. Radiation Ther. Onc., 6 : 1-16, 1972.

28）下里幸雄, 馬場謙介, 大星章一, 他：肺癌に対 するMitomycin C気管支動脈内投与の病理組織 学的検討. 癌の臨床, $14: 945-957,1968$.

（原稿受付 1982年10月 7 日）

\title{
Non-Surgical Treatment of Non-Small \\ Cell Carcinoma of the Lung
}

\author{
Samon Miyata \\ Department of Radiology, Kanazawa University, \\ School of Medicine, Kanazawa
}

The effects of radiotherapy in 256 cases of inoperable non-small cell carcinoma of the lung were analyzed.

The results and conclusion are;

1) Survival rate of all 256 cases was 1 year in 74/256 (28.9\%), 2 years $15 / 229$ (6.6\%), 3 years $5 / 202(2.5 \%)$ and the median survival was 5.9 months.

2) As stage advances, the survival rate generally decreased. There were no differences of the survival rates of squamous cell carcinoma and adenocarcinoma, and the survival rate of large cell carcinoma was the worst. Furthermore, according to the irradiation dose, survival in cases that received irradiation of over 5000 rad was higher than in cases receiving under $5000 \mathrm{rad}$. The higher irradiation dose gave the increased tumor effect and it considered as one reason for better survival.

3) Curability was obtained in stage I cases with irradiation of over $6000 \mathrm{rad}$, however it was rather poor in stage II. Extension of survival term was considered possible by aggressive radiotherapy of local advanced squamous cell carcinoma.

4) Increased radiotherapeutic effects can be obtained by the combined use of bronchial arterial infusion, with possible extension of survival. 